\title{
Assessing the living and dead proportions of cold-water coral colonies: implications for deep-water Marine protected area monitoring in a changing ocean
}

\author{
Johanne Vad \\ Covadonga Orejas $^{3}$, Juan Moreno-Navas ${ }^{4}$ \\ Helen S Findlay \\ 1 \\ ${ }^{1}$ School of Engineering Geoscience Infrastructure and Society, Heriot-Watt University, Edinburgh, United Kingdom \\ 2 School of Geoscience, Grant Institute, University of Edinburgh, Edinburgh, United Kingdom \\ ${ }^{3}$ Centro de Oceanográfico de Baleares, Instituto Español de Oceanografia, Palma de Mallorca, Islas Baleares, Spain \\ 4 Physical Oceanography Research Group, Universidad de Málaga, Málaga, Spain \\ 5 Plymouth Marine Laboratory, Plymouth, UK \\ ${ }^{6}$ Center for Marine Science, University of North Carolina at Wilmington, Wilmington, North Carolina, United States \\ Corresponding Authors: Johanne Vad, J Murray Roberts \\ Email address: jv63@hw.ac.uk, Murray.Roberts@ed.ac.uk
} J Murray Roberts ${ }^{\text {Corresp. } 2,6}$

Coral growth patterns result from an interplay of coral biology and environmental conditions. In this study colony size and proportion of live and dead skeleton in the coldwater coral (CWC) Lophelia pertusa (Linnaeus, 1758) were measured using video footage from Remotely Operated Vehicle (ROV) transects conducted at the inshore Mingulay Reef Complex (MRC) and at the offshore PISCES site (Rockall Bank) in the NE Atlantic. The main goal of this paper was to explore the development of a simple method to quantify coral growth and its potential application as an assessment tool of the health of these remote habitats. Eighteen colonies were selected and whole colony and dead / living layer size were measured. Live to dead layer ratios for each colony were then determined and analysed. Age of each colony was estimated using previously published data. Our paper shows that: (1) two distinct morphotypes can be described: at the MRC, colonies displayed a 'cauliflower-shaped' morphotype whereas at the PISCES site, colonies presented a more flattened 'bush-shaped' morphotype (2) Living layer size was positively correlated with whole colony size (3) Live to dead layer ratio was negatively correlated to whole colony size (4) Live to dead layer ratio never exceeded 0.27 These results suggest that as a colony develops and its growth rate slows down, the proportion of living polyps in the colony decreases. Furthermore, at least $73 \%$ of L. pertusa colonies are composed of exposed dead coral skeleton, vulnerable to ocean acidification and the associated shallowing of the aragonite saturation horizon, with significant implications for future deep-sea reef framework integrity. The clear visual contrast between white / pale living and grey / dark dead portions of the colonies also gives a new way by which they can be visually monitored over time. The increased use of marine autonomous survey vehicles 
offers an important new platform from which such a surveying technique could be applied to monitor deep-water marine protected areas in the future. 
1 Title: Assessing the living and dead proportions of cold-water coral colonies: implications

2 for deep-water Marine Protected Area monitoring in a Changing Ocean

3

4 Johanne Vad ${ }^{1,2 *}$, Covadonga Orejas ${ }^{3}$, Juan Moreno-Navas ${ }^{4}$, Helen S Findlay ${ }^{5}, \mathrm{~J}_{\text {Murray Roberts }}^{2}$,

$5 \quad 6^{*}$

6 *Corresponding author: jv63@hw.ac.uk; murray.roberts@ed.ac.uk

7

81 Heriot-Watt University, School of Engineering Geoscience Infrastructure and Society,

9 Edinburgh, United Kingdom

10

112 University of Edinburgh, School of Geoscience, Grant Institute, Edinburgh, United Kingdom

12

133 Instituto Español de Oceanografía (IEO), Centro Oceanográfico de Baleares (COB), Islas

14 Baleares, Spain

15

164 Universidad de Málaga, Physical Oceanography Research Group, Málaga, Spain

17

185 Plymouth Marine Laboratory, Plymouth, United Kingdom

19

206 Center for Marine Science, University of North Carolina Wilmington, Wilmington, NC, United

21 States of America

22

23 Short title: cold-water coral growth assessment 


\section{Abstract}

25 Coral growth patterns result from an interplay of coral biology and environmental conditions. In

26 this study colony size and proportion of live and dead skeleton in the cold-water coral (CWC)

27 Lophelia pertusa (Linnaeus, 1758) were measured using video footage from Remotely Operated

28 Vehicle (ROV) transects conducted at the inshore Mingulay Reef Complex (MRC) and at the

29 offshore PISCES site (Rockall Bank) in the NE Atlantic. The main goal of this paper was to

30 explore the development of a simple method to quantify coral growth and its potential

31 application as an assessment tool of the health of these remote habitats. Eighteen colonies were

32 selected and whole colony and dead / living layer size were measured. Live to dead layer ratios

33 for each colony were then determined and analysed. Age of each colony was estimated using

34 previously published data.

35 Our paper shows that:

36 (1) two distinct morphotypes can be described: at the MRC, colonies displayed a 'cauliflower-shaped' morphotype whereas at the PISCES site, colonies presented a more flattened 'bush-shaped' morphotype

(2) Living layer size was positively correlated with whole colony size

(3) Live to dead layer ratio was negatively correlated to whole colony size

(4) Live to dead layer ratio never exceeded 0.27

These results suggest that as a colony develops and its growth rate slows down, the proportion of

43 living polyps in the colony decreases. Furthermore, at least $73 \%$ of L. pertusa colonies are composed of exposed dead coral skeleton, vulnerable to ocean acidification and the associated shallowing of the aragonite saturation horizon, with significant implications for future deep-sea reef framework integrity. The clear visual contrast between white / pale living and grey / dark 
47 dead portions of the colonies also gives a new way by which they can be visually monitored over

48 time. The increased use of marine autonomous survey vehicles offers an important new platform

49 from which such a surveying technique could be applied to monitor deep-water marine protected

50 areas in the future. 


\section{INTRODUCTION}

52 Some species of cold-water corals (CWC) can form complex 3-dimensional reef

53 frameworks supporting biodiversity hotspots (e.g. Freiwald 2002; Roberts et al. 2009; Henry et

54 al. 2010 Buhl-Mortensen et al. 2010), but several anthropogenic activities are putting them at

55 risk. Fisheries, oil and gas extraction, deep-sea mining as well as the effects of climate change,

56 including ocean acidification (OA), are threatening these important benthic communities (e.g.

57 Koslow et al. 2000; Roberts et al. 2006; Hall-Spencer et al. 2008; Hennige et al. 2015; Büscher

58 et al. 2017). One of the factors that clearly defines the resilience of such fragile benthic

59 communities to natural and anthropogenic impacts, as well as the population dynamics of clonal

60 species such as corals, is their growth rate and growth pattern (Hughes 1987). However, in

61 comparison with their tropical counterparts, azooxanthellate CWC still remain less known and

62 much less studied due to the difficulties in accessing their remote deep-sea locations. Coral

63 growth is controlled by a range of environmental factors. In deep waters ( $>100 \mathrm{~m})$, local

64 hydrodynamics and energy supply (Mienis et al. 2007), as well as temperature (Thresher 2009)

65 play a central role for survival and growth of CWC. For many years, these factors have also been

66 known to modify tropical coral phenotype. For example, branching tropical corals tend to

67 become less robust with depth (Barnes 1973) but less is known about the influence of

68 environmental factors on CWC phenotypes. Over the last 15 years improvements in aquaria

69 facilities (e.g. Roberts \& Anderson 2002; Olariaga et al. 2009) and in the growing use of high

70 resolution visual surveys from Remotely Operated Vehicles (ROV), have allowed to advance our

71 understanding of these previously unreachable ecosystems. Video footage and still images

72 obtained with ROVs have become powerful non-destructive approaches to study several aspects

73 of CWCs and the communities they support including their occurrence, density and geographic 
74 distribution (e.g. Orejas et al. 2009; Arnaud-Haond et al. 2015), bathymetric distribution, coral

75 size classes and orientation (Gori et al. 2013) and relationship with associated species (Purser et 76 al. 2013).

77 Our knowledge of CWC growth rates has also dramatically improved thanks to experimental 78 studies (e.g. Orejas et al. 2008, $2011 \mathrm{a}, \mathrm{b}$; Brooke and Young 2009; Lartaud et al. 2013) and field 79 measurements on man-made structures (Gass and Roberts 2006, 2010; Larcom et al. 2014).

80 Moreover, data both on abiotic parameters and from video and photographic records can now 81 allow morphological patterns and colony biometrics to be described, quantified and related to 82 abiotic environmental data. This synergistic approach linking colony morphology and size to 83 environmental parameters is needed to gain deeper understanding of the relationship between 84 those drivers and CWC growth. These are critical steps necessary if field monitoring 85 programmes are to be established to understand and record the implications of global change on 86 CWC habitats.

To date most laboratory CWC studies have worked on Lophelia pertusa (Linnaeus, 1758).

88 Several studies show the degree of adaptation of this species to temperature changes (e.g. Dodds 89 et al. 2007; Brooke et al. 2013; Naumann et al. 2014). In recent years, much effort has been made to understand the effects of ocean acidification on L. pertusa growth (e.g. Form and

91 Riebesell 2011; McCulloch et al. 2012; Maier et al. 2013; Movilla et al. 2014; Hennige et al. 92 2015) and the carbonate chemistry of the environments where it occurs (e.g. Findlay et al. 2014).

93 The recent results from studies performed using L. pertusa from the Mingulay Reef Complex 94 (Roberts et al. 2005, 2009), indicated that this species was fairly resilient under OA scenarios 95 under short timescales of 21 to 89 days (Maier et al. 2013; Hennige et al. 2014a). However, over 96 longer experimental time periods of a year, biomineralisation processes in L. pertusa changed 
97 inducing modifications in polyp morphology and making the skeleton more fragile, with

98 additional evidence that dead portions of the skeleton not covered by living coral tissue were

99 particularly vulnerable (Hennige et al. 2015). Thus, quantifying the proportions of live and dead

100 coral during field surveys is an essential prerequisite of any long-term monitoring programme to

101 follow CWC framework reefs over time.

102 In this study, we explore a new approach to assess $L$. pertusa colony size, and the

103 proportion of live and dead coral in each colony by using opportunistic measurements from high

104 definition video footage recorded from two sites in the NE Atlantic, one inshore (the Mingulay

105 Reef complex) and one offshore (the PISCES site). We hypothesize that proportion of live and

106 dead coral in L. pertusa colonies will differ between and within sites as abiotic conditions

107 change. This opportunistic study was completed with the footage available from the 2012

108 Changing Oceans Expedition (RRS James Cook cruise 073) and revealed: (1) that distinct colony

109 morphotypes dominate each study site and (2) that both morphotypes were predominantly

110 composed of dead coral with smaller proportions of live coral polyps found in all colonies

111 analysed. Based on these preliminary results, we explore the potential applications of this coral

112 growth quantification as an assessment tool to determine the health and conservation status of

113 deep-sea framework building corals.

115 MATERIAL \& METHODS

\section{Research area}

117 The Mingulay Reef Complex (MRC) is located in the Sea of the Hebrides between the

118 uninhabited island of Mingulay and the west coast of Scotland (Fig. 1). Within the MRC,

119 Mingulay Reef Area 1 (MR) constitutes two asymmetric east-west oriented ridges 1.5 and 2.3 
$120 \mathrm{~km}$ long respectively separated by an approximately $700 \mathrm{~m}$ wide gap (Fig. 1). The so-called

121 Banana reef (BR) to the southeast of MR, is formed by a thin $2.5 \mathrm{~km}$-long ridge (Fig. 1) (Roberts

122 et al. 2009; Duineveld et al. 2012). The coral colonies forming the MRC grow preferentially on

123 the topographic highs created by the flanks and crests of ridges formed by dolorite sills (MR) and

124 igneous intrusions (BR) that outcrop at the seabed (Roberts et al. 2009). Video transects used in

125 this study revealed a high coral cover but our analyses were at times constrained by poor

126 visibility at this site in the post-spring bloom time period when the surveys were carried (RRS

127 James Cook cruise 073, Roberts et al. 2013).

128 Comprehensive information on abiotic factors were available throughout MRC: depth and

129 site carbonate chemistry were known thanks to successive surveys starting in 2003 (Roberts et

130 al. 2005, 2009; Davies et al. 2009; Findlay et al. 2013) . Furthermore average current speed,

131 current speed standard deviation, maximum current speed, aspect, slope as well as rugosity were

132 extracted from a high resolution 3D hydrodynamic model with $100 \mathrm{~m}$ spatial resolution

133 developed at constant values for temperature and salinity (Moreno-Navas et al. 2014). These

134 seabed terrain variables were calculated with a spatial resolution of $3 \mathrm{~m}$ using ArcGis 9.2 with

135 ESRI spatial analysis extension (Moreno-Navas et al. 2014).

136 The other study location was the PISCES site on the Rockall Bank, 460km west of

137 Scotland. The offshore PISCES site was first described by Wilson (1979) during research

138 submersible dives using PISCES III in 1973. However, it has been less intensively studied than

139 the MRC. In this area, L. pertusa shows a discontinuous patchy distribution of 'Wilson rings',

140 mostly at depths of 220-350 m where coral colonies grow on the flanks of Pleistocene iceberg

141 ploughmarks (Wilson 1979). Video transects recorded here also covered extensive off-reef

142 habitats, illustrating the sparsity of the coral cover at the PISCES site in comparison with MRC 
143 (RRS James Cook cruise 073, Roberts et al. 2013). The hydrodynamic model available for MRC

144 do not extend to the PISCES site and abiotic factors values for colonies for the PISCES site were

145 therefore not available.

146

147 Sampling and video processing

148 In the present study, video surveys were conducted at MRC and PISCES, during the 2012

149 Changing Oceans Expedition (RRS James Cook cruise 073, Roberts et al. 2013) carried out

150 through the Natural Environment Research Council's UK Ocean Acidification research program

151 (UKOA, NERC). The cruise took place in May-June 2012 and high definition video footage was

152 recorded with the Holland-1 remotely operated vehicle (ROV), from the Irish Marine Institute

153 (Galway). ROV position was recorded by an ultra-short-baseline system (USBL) underwater

154 positioning system.

155 A total of 9 video surveys, 7 from MRC (6 from MR and 1 from BR) and 2 from PISCES

156 were used in this study. From these dives, all colonies (1) visibly distinctive from others on the

157 video footage (2) close enough to the ROV for precise measurements (ROV within $1 \mathrm{~m}$ of the

158 colony) and (3) displaying a clearly visible separation between the darker dead and the brighter

159 white living layers of the coral colony were selected. Still images of those colonies were

160 extracted from the videos (Fig. 2 and 3). In this study, a L. pertusa colony refers to a distinctive

161 coral sub-entity of the reef. We recognise that skeletal fusion in L. pertusa is common (Hennige

162 et al. 2014b) and therefore do not use the word colony to imply any genetic differentiation.

163 Universal time codes were not embedded in the high definition footage but were available

164 via low definition images recorded by three additional ROV cameras. Synchronisation of the two

165 video records enabled the time each colony was filmed to be extracted and from this their precise 
166 positions (Universal Transverse Mercator) were logged using the Ocean Floor Observation

167 Protocol (OFOP) (Huetten and Greinert 2008) navigation system output. Videos were replayed 168 and processed using iMovie (Apple Inc.).

\section{Colony measurements and age estimation}

The Holland-1 ROV was equipped with two laser scale pointers separated by $100 \mathrm{~mm}$

172 which were used to assess overall coral colony size and the thicknesses of the dead and living

173 layers within each colony. On rare occasions, the two laser beams were not visible because of

174 high water turbidity. In these cases, it was possible to estimate colony sizes using the known

175 dimensions (400 $\mathrm{mm}$ width) of a bio-box sampling unit mounted immediately adjacent to the

176 corals in the field of view at the front of the ROV (see figure 2a). To limit perspective errors only

177 colonies immediately adjacent to the bio-box were measured in this way.

178 Each colony image was processed using the free software ImageJ (Rasband, W.S., ImageJ,

179 U. S. National Institutes of Health, Bethesda, Maryland, USA, http://imagej.nih.gov/ij/, 1997-

180 2014). For each image, the size of the whole colony (from base to top) and of each layer (dead

181 and living part) was measured at five different points on each colony in order to best catch intra-

182 individual variability. To perform these measurements, the growth direction of the coral branches

183 was followed but taken into account the three dimensional nature of the colonies as shown in

184 figures 2 and 3 panels $\mathrm{b}, \mathrm{c}$ and $\mathrm{d}$. Thus, after image processing, five measurements per colony

185 were available for the whole colony size as well as for the dead and the living layer (Fig. 2 and

186 3). The 'living layer thickness : whole colony size' ratio (LL : WC ratio) was also calculated for

187 each colony dividing the thickness of the living layer by the size of the whole colony.

188 Age for each colony was determined using a growth rate estimation of $26 \pm 5 \mathrm{~mm} \mathrm{yr}^{-1}$ (Gass and 
189 Roberts 2006). Although several studies have assessed different L. pertusa growth rate using in-

190 situ measurement, coral staining and aquaria approaches (Duncan 1877; Dons 1944; Orejas et al.

191 2008, 2011b; Brooke et al. 2009; Lartaud et al. 2012), the Gass and Roberts (2006) estimation is

192 based on in situ colony observation over time in the North Sea using ROV recorded video

193 footage and therefore gives the closest match geographically and in terms of water depth as well

194 as technologically to this study.

195

196 Numerical and statistical analysis

197 Average values of layer thicknesses, whole colony sizes and LL : WC ratios were

198 determined for each colony.

199 To determine differences in measurements between colonies across sites, two-sided two

200 samples Wilcoxon tests were performed for each metric. Further statistical analysis was also

201 carried out to determine Spearman correlation factors and p-values between the whole colony

202 size and the living layer thickness as well as the LL : WC ratio for each colony. For these

203 calculations, all of the measurements were used (18 colonies x 5 replicates for each colony).

204 To determine the influence of abiotic factors on CWC growth, average current speed,

205 current speed standard deviation, current speed maximum as well as depth and aspect (facing

206 gradient of the seabed), slope (gradient) and rugosity were extracted at each MRC colony

207 location from the model described by Moreno-Navas et al. (2014). This model was not available

208 for the PISCES site colonies, it was developed only for MRC with constant temperature and

209 salinity (Moreno-Navas et al. 2014). Spearman correlation coefficient and p-value were

210 respectively calculated between these abiotic factors and each layer size as well as -log

211 transformed ratio. All statistical handling was performed with the free software R (R 
212 Development Core Team 2011).

213

214 RESULTS

215 Lophelia pertusa colonies morphotypes from MRC and PISCES

216 In total 18 colonies from nine transects varying from 63 to $1,865 \mathrm{~m}$ in length, displayed a

217 clear live / dead layer separation and could thus be used in the analysis (table 1, Fig. 1). Fourteen

218 of these colonies were located at MRC (colonies 1 to 14) and the 4 remaining were situated in

219 PISCES (colonies 15 to 18) (table 1).

220 Differences in colony morphology were identified between the two areas: L. pertusa

221 colonies at MRC displayed a spherical “cauliflower” shape (sensu Freiwald et al. 1999; Rogers

222 2004; Orejas et al. 2009), resulting from a multidirectional growth (Fig. 2). On the contrary, $L$.

223 pertusa colonies at PISCES were less abundant than in MRC, flattened and horizontally planar in

224 shape, emerging from a horizontal growth (Fig. 3). Wilson (1979) called the PISCES

225 morphotype 'bush-shaped' and these colonies displayed a less compact shape than those at MRC

226 with some portions of the colonies not covered by living polyps (Fig. 3).

227

228 Colony size and layer thickness estimation

229 Overall L. pertusa whole colony size ranged from $324 \pm 43 \mathrm{~mm}$ (Colony 2, MRC) to 1,344

$230 \pm 115 \mathrm{~mm}$ (Colony 13, MRC) (Table 2, Fig. 4). Therefore, the estimated ages of the colonies

231 observed in this study ranged from $12.9 \pm 3.1$ (colony 2, MRC) to $53.7 \pm 11.7$ years old (colony

232 13, MRC) (Table 2).

233 The living layer size stayed relatively stable: varying from a minimum of $48 \pm 13 \mathrm{~mm}$ (colony 2 ,

$234 \mathrm{MRC}$ ) to a maximum of $260 \pm 10 \mathrm{~mm}$ (colony 5, MRC) (Table 2, Fig.4). In contrast to the living 
235 layer, the dead layer thickness varied notably between colonies, accounting for the variability of

236 the whole colony size described above. Colony 13 showed the largest dead layer $(1,208 \pm 124$

$237 \mathrm{~mm})$ whereas the smallest dead layer $(207 \pm 26 \mathrm{~mm})$ was measured in colony 9 (Table 2, Fig.4).

238 Difference in layer sizes and whole colony sizes between sites was not observed. However,

239 living and dead layer thickness variations were overall less notable at the PISCES site (Table 2,

240 Fig.4).

241 In all the colonies measured in this study, the living layer never exceeded one fourth of the 242 whole colony size, resulting in LL : WC ratios ranging from $0.10 \pm 0.02$ (colony $13, \mathrm{MRC}$ ) to $2430.27 \pm 0.02$ (colony 5, MRC) (Table 2). LL : WC ratio variation for colonies from PISCES was 244 very narrow with minimum values of $0.16 \pm 0.02$ (colony 16) to maximal of $0.18 \pm 0.03$ (colony 24515 and 18) (Table 2).

247 Statistical analysis

248 All two-sided two samples Wilcoxon tests (on layer thicknesses, whole colony sizes and -

249 Log transformed LL : WC ratio) produced non-significant p-values (ranging from 0.1515 to 250 0.915) showing no statistically significant differences between the colonies across sites (Table 3)

251 for all the metrics measured here.

252 Spearman correlation tests however revealed a significant positive correlation $(p$-value $=$ $\left.2531.1 \mathrm{e}^{-11}, \rho=0.63\right)$ between whole colony size and living layer size and a significant negative 254 correlation ( $p$-value $=4.4 \mathrm{e}^{-04}, \rho=-0.35$ ) between whole colony size and LL : WC ratio (Fig. 5). 255 Correlation coefficients between living and dead layer thicknesses and abiotic factors 256 available at MRC (depth, average current speed, aspect, slope and rugosity) (Table 4) were 257 overall low and not significant as all p-values varied between 0.36 and 0.98 . 


\section{DISCUSSION}

\section{Lophelia pertusa morphotypes and the influence of environmental factors}

261 This study reveals the presence of two distinct L. pertusa colony morphologies at MRC

262 ("cauliflower") and PISCES area ("bush-shaped”). Different morphotypes have already been

263 documented in tropical scleractinian corals, which are known to display several growth forms

264 due to an interplay between factors including: (1) genetic factors (Willis and Ayre 1985), (2)

265 different influences of abiotic factors such as depth as a proxy for temperature (Barnes 1973),

266 water movement or turbidity (Foster 1979; Miller 1995; Dullo 2005; Smith et al. 2007) or (3) a

267 combination of genetic and abiotic features (e.g. Via and Lande 1985). Similar observations

268 concerning CWC colony plasticity have been so far reported by Freiwald (2002), Orejas et al.

269 (2009) and Gori et al. (2013). Unravelling environmental conditions leading to the differentiation

270 in L. pertusa colony shape could lead to the use of morphotypes as a bio-indicator of

271 environmental conditions, an idea initially suggested by Grigg (1972) for gorgonians.

272 The different morphologies found in the two sites could be due to differences in

273 environmental conditions experienced by the colonies at these locations. MRC and PISCES are

274 respectively constituted by reef structures and coral patches (Wilson 1979; Roberts et al. 2009).

275 These two sites also display different depth ranges: the reefs studied in the MRC are located

276 between 100 - $137 \mathrm{~m}$ depth whereas the PISCES coral patches were found at a deeper

277 bathymetric range of $230-266 \mathrm{~m}$. Moreover, the MRC site displayed distinct temperature and

278 salinity properties compared to PISCES (Fig. 6), as MRC has a marked coastal influence, and

279 addition of fresh water run-off. Oxygen concentration and Dissolved Inorganic Carbon (DIC)

280 also displayed lower values at PISCES than at MRC as a consequence of the deeper depth range 
281 of PISCES (Findlay et al. 2014).

282 Furthermore, at MRC, the presence of two distinct mechanisms controlling food supply has

283 previously been described (Davies et al. 2009; Duineveld et al. 2012; Findlay et al. 2013).

284 Colonies at MRC receives warmer plankton-rich water thanks to a tidal downwelling of surface

285 water which further circulates to colonies located at BR. Colonies at MR benefit from re-

286 suspended matter from advected deep bottom water (Davies et al. 2009; Duineveld et al. 2012;

287 Findlay et al. 2013).

288 The oceanographic and food supply regimes at the PISCES site are not yet as well characterised.

289 Particulate Organic Carbon (POC) sampling was carried out during the JC073 Cruise but

290 analysed data is unfortunately not yet available. High POC values have been demonstrated to be

291 an important carbon source for benthic communities including suspension feeding corals and

292 gorgonians (Ribes et al. 1998; Houlbrèque and Ferrier-Pages 2009; Wagner et al. 2011). Here

293 we could hypothesize that if higher POC values at MRC were measured, POC could explain the

294 higher number of well-developed cauliflower colonies present in MRC compared to PISCES

295 site. Indeed, the MRC site displayed a coral population with colonies at different development

296 degrees (different sizes) where as PISCS site displayed homogenous large colonies, perhaps

297 indicative of a more senescent population. This could be better determined with the future

298 addition of POC data.

299

300 Colony size, layer thickness estimation and environmental factors

301 Total colony size and dead layer thickness measured here displayed a higher inter-colony

302 variability than living layer thickness and LL : WC ratio. However, no significant differences

303 could be detected between MRC and PISCES sites. Interestingly living layer thickness was 
304 positively correlated to the whole colony size whereas the LL : WC ratio was negatively

305 correlated to the whole colony size (Fig. 5). This could suggest that as a colony develops and its

306 growth rate slows down (as suggest by Brooke and Young 2009 and Lartaud et al. 2013), the

307 proportion of living polyps in the colony decreases. To our knowledge this constitutes the first

308 quantitative analysis of the layering displayed by a reef framework forming CWC. However, the

309 pattern observed here is similar to those described in the facultative zooxanthellate scleractinian

310 coral Oculina varicosa (Reed 2002). In Reed's work it was argued that the death of deep-

311 dwelling azooxanthellate coral tissue was due to limited water flow in the core of these colonies

312 because of the dense branching network (Reed 2002). Flow intensity has been previously

313 demonstrated to influence capture rate of tropical corals (McFadden 1986; Helmuth and Sebens

314 1993; Johnson and Sebens 1993; Helmuth et al. 1997; Sebens et al. 1998; Hoogenboom et al.

315 2008). In L. pertusa, water velocity is also known to impact capture efficiency (Purser et al.

316 2010; Orejas et al. 2016). However, no significant correlation between abiotic factors including

317 average current speed and layer sizes could here be found to explain the reasons for the

318 differences detected in the colonies at MRC. The 3D hydrodynamic model used to extract abiotic

319 data (Moreno-Navas et al. 2014) has a $100 \mathrm{~m}$ spatial resolution, which is most probably too

320 coarse to reveal the impact of the hydrodynamic on a single colony development.

321 It is important to take into account that the LL : WC ratio as calculated here, never

322 exceeded 0.27 meaning that the living layer never represents more than one quarter of the whole

323 colony size. Initial short-term laboratory experiments show that $L$. pertusa seemed resilient to

324 change in water chemistry and lower $\mathrm{pH}$ conditions (Maier et al. 2013, Hennige et al. 2014a).

325 However, a recent study published by Hennige et al. (2015) shows that even though L. pertusa is

326 able to physiologically adapt to OA conditions over a longer time period, its skeleton becomes 
327 significantly weaker, leading to breakage of the framework and higher susceptibility to

328 bioerosion and mechanical damage. As the dead layer constitutes the great majority of a $L$.

329 pertusa colony as shown by our measurements, the consequences of OA on CWC reefs and the

330 habitats they support, could be worse than expected. A negative influence of low $\mathrm{pH}$ levels on

331 the dead layer of the colony would lead to a weakening of the skeleton and its breakage, with the

332 consequent destruction of the three-dimensional structure of the colonies and the reef. Further

333 investigation of colony layering and morphotypes at other reefs, as well as growth rate in situ

334 validations, is needed to further investigate the use of LL : WC ratio measurements as a bio-

335 indicator of colony health and susceptibility to OA.

336

337 Colony health indicators are vital in order to develop robust protocols to monitor changes in

338 CWC colony health over time, particularly to assess the effectiveness of deep-water Marine

339 Protected Areas (MPA) created for their long-term conservation. Recent work has shown the

340 slow growth rate and low recovery potential of deep-water coral habitats at the Darwin Mounds

341 at 1,000 m water depth in the Rockall Trough (Huvenne et al. 2016). Our work demonstrates a

342 simple metric that could be scaled up using already collected ROV footage or autonomous

343 survey approaches (see Wynn et al. 2014) to characterise larger habitat areas and gather datasets

344 from many more coral colonies than possible in the present study. When combined with

345 machine-learning image analysis and a robust understanding of deep-water MPA network

346 connectivity (Fox et al. 2016) these approaches will greatly improve our understanding of deep-

347 sea habitats and our ability to monitor them over time.

348

349 ACKNOWLEDGEMENTS 
$350 \mathrm{JV}, \mathrm{JMN}$ and JMR acknowledge additional support from University of Edinburgh Changing

351 Ocean group. JV and CO acknowledge support from the IEO. We thank the captain, crew and

352 scientific participants of RRS James Cook cruise 073 for assistance at sea.

353

354

355

356

357

358

359

360

361

362

363

364

365

366

367

368

369

370

371

372

373

\section{REFERENCES}

\section{Arnaud-Haond S., van den Beld I.M.J., Becheler R., Orejas C., Menot L., Frank N.,} Grehan A., Bourillet J.F. (2015) Two "pillars" of cold-water corals reefs along Atlantic European Margins: Prevalent association of Madrepora occulata with Lophelia pertusa, from reef to colony scale. Deep-Sea Research Part II, 1-10.

Barnes D.J. (1973) Growth in colonial scleractinians. Bulletin of Marine Science 23, 280-298.

Brooke S. and Young C.M. (2009) In-situ measurement of survival and growth of Lophelia pertusa in the northern Gulf of Mexico. Marine Ecology Progress Series 397,153-161.

Brooke S., Ross S.W., Bane J.M., Seim H.E. and Young C.M. (2013) Temperature tolerance of deep-sea coral Lophelia pertusa from the southeastern United States. Deep-Sea Research Part II 92, 240-248.

Buhl-Mortensen L., Vanreusel A., Gooday A. J., Levin L. A., Priede I. G., Buhl-Mortensen P., et al. (2010). Biological structures as a source of habitat heterogeneity and biodiversity on the deep ocean margins. Mar. Ecol. 31, 21-50.

Büscher J.V., Form A.U., Riebesell U. (2017) Interactive Effects of Ocean Acidification and Warming on Growth, Fitness and Survival of the Cold-Water Coral Lophelia pertusa under Different Food Availabilities. Frontiers in Marine Science 4:101

\section{Davies A.J., Duineveld G.C.A., Lavaleye M.S.S., Bergman M.J.N., van Haren H. and} Roberts J.M. (2009) Downwelling and deep-water bottom currents as food supply mechnisms to the cold-water coral Lophelia pertusa (Scleractinia) at the Mingulay Reef 
complex. Limnology and Oceanography 54, 620-629.

375

376

377

378

380

381

382

383

384

385

386

387

388

389

390

391

392

393

394

395

396

De Mol L., Van Rooij D., Pirlet H., Greinert J., Frank N., Quemmerais F. and Henriet J.P. (2011) Cold-water coral habitats in the Penmarc'h and Guilvinec Canyons (Bay of Biscay): Deep-water versus shallow-water settings. Marine Geology 282, 40-52.

Dodds L.A., Roberts J.M., Taylor A.C. and Marubini F. (2007) Metabolic tolerance of the cold-water coral Lopehlia pertusa (Scleractinia) to temperature and dissolved oxygen change. Journal of Experimental Biology and Ecology 349, 205-214.

Dons C. (1944) Norges korallrev. Kongelige Norske videnskabernes selskab forhandlinger 16, $37-82$.

Duineveld G.C.A., Jeffreys R.M., Lavaleye M.S.S., Davies A.J., Bergman M.J.N., Watmough T. and Witbaard R. (2012) Spatial and tidal variation in food supply to shallow cold-water coral reefs of the Mingulay Reef complex (Outer Hebrides, Scotland). Marine Ecology Progress Series 444, 97-115.

Dullo W.C. (2005) Coral growth and reef growth: a brief review. Facies 51, 33-48.

Duncan PM (1877) On the rapidity of growth and variability of some Madreporaria on an Atlantic cable, with remarks upon the rate of accumulation of foraminiferal deposits. Proceedings of the Royal Society of London 26: 133-137

Findlay H.S., Artioli Y., Moreno Navas J., Hennige S.J., Wicks L.C., Huvenne V.A., Woodward E.M. and Roberts J.M. (2013) Tidal downwelling and implications for the carbon biogeochemistry of cold-water corals in relation to future ocean acidification and warming. Global Change Biology 19, 2708-2719.

Findlay H.S., Hennige S.J., Wicks L.C., Moreno-Navas J., Malcom E., Woodward S. and Roberts J.M. (2014) Fine-scale nutrient and carbonate system dynamic around the cold- 
water coral reefs in the Northeast Atlantic. Scientific Reports 4, 1-10.

398 Form A.U. and Riebesell U. (2011) Acclimation to ocean acidification during long-term $\mathrm{CO}_{2}$

399 exposure in the cold-water coral Lophelia pertusa. Global Change Biology 18, 843-853.

400 Foster A.B. (1979) Phenotypic plasticity in the reef corals Montastrea annularis and Siderastrea $401 \quad$ sideria. Journal of Experimental Marine Biology and Ecology 39, 25-54.

402 Fox A., Henry L.A., Corne D.W. and Roberts J.M. (2016) Sensitivity of a marine protected 403 area network to shifts in atmospheric state and ocean circulation. Royal Society Open $404 \quad$ Science 3,160494

405 Freiwald A., Wilson J.B. and Henrich R. (1999) Grounding Pleistocene icebergs shape recent 406 deep-water coral reefs. Sedimentary Geology 125, 1-8.

407 Freiwald A. (2002) Reef-Forming Cold-Water Corals. In Ocean Margin Systems. Berlin 408 Heidelberg.

409 Gass S.E. and Roberts J.M. (2006) The occurrence of the cold-water coral Lophelia pertusa

410 (Scleractinia) on oil and gas platforms in the North Sea: Colony growth, recruitment and 411 environmental controls on distribution. Marine Pollution Bulletin 52, 549-559.

412 Gass S.E. and Roberts J.M. (2011) Growth and branching patterns of Lophelia pertusa 413 (Scleractinia) from the North Sea. Journal of the Marine Biological Association of the $414 \quad$ United Kingdom 91, 831-835.

415 Gori A., Orejas C., Madurell T., Bramanti L., Martins M., Quintanilla E., Marti-Puig P., 416 Lo Iacono C., Puis P., Requena S., Greenacre M. and Gili JM. (2013) Bathymetrical 417 distribution and size structure of cold-water coral populations in the Cap de Creus and 418 Lacaze-Duthiers canyons (northwestern Mediterranean). Biogeosciences 10, 2049-2060.

419 Grigg R.W. (1972) Orientation and growth form of sea fans. Limnology and Oceanography 
17:185-192.

421

422

423

424

425

426

427

428

429

430

431

432

433

434

435

436

437

438

439

440

441

442

Hall-Spencer J.M., Rodolfo-Metalpa R., Martin S., Ransome E., Fine M., Turner S.M., Rowley S.J., Tedesco D. and Buia M.C. (2008) Volcanic carbon dioxide vents show ecosystem effects of ocean acidification. Nature 454, 96-99.

Helmuth B.S.T. and Sebens K.P. (1993) The influence of colony morphology and orientation to flow on particle capture by the scleractinian coral Agaricia agaricites (Linnaeus). Journal of Experimental Marine Ecology 165, 251-278.

Helmuth B.S.T., Sebens K.P. and Daniel T.L. (1997) Morphological variation in coral aggregations: branch spacing and mass flux to coral tissues. Journal of Experimental Marine Biology and Ecology 209: 233-259.

Hennige S.J., Wicks L.C., Kamenos N.A., Bakker D., Findlay H.S., Dumousseaud C. and Roberts J.M. (2014a) Short-term metabolic and growth responses of the cold-water coral Lophelia pertusa to ocean acidification. Deep-Sea Research Part II 99, 27-35.

Hennige S.J., Morrison C.L., Form A.U., Büscher J., Kamenos N. A. and Roberts J.M. (2014b) Self-recognition in coral facilitates deep-sea habitat engineering. Scientific Reports $4,1-7$.

Hennige S.J., Wicks L.C., Kamenos N.A., Perna G., Findlay H.S. and Roberts J.M. (2015) Hidden impacts of ocean acidification to live and dead coral framework. Proceedings of the Royal Society B 282: 1-10.

Henry L.A., Davies A.J. and Roberts J.M. (2010) Beta diversity of cold-water coral reef communities off western Scotland. Coral Reefs 29, 427-436.

Hoogenboom M.O., Connolly S.R. and Anthony K.R.N. (2008) Interactions between morphological and physiological plasticity optimize energy acquisition in corals. Ecology 
89, 1144-1154.

444 Houlbrèque F. and Ferrier-Pages C. (2009) Heterotrophy in tropical scleractinian corals. 445 Biological Reviews 84, 1-17.

446 Hughes T.P. (1987) Skeletal density and growth form of corals. Marine Ecology Progress Series $35,259-266$.

Johnson A.S. and Sebens K.P. (1993) Consequences of a flattened morphology: effects of flow on feeding rates of scleractinian coral Meandrina meandrites. Marine Ecology Progress Series 99, 99-114.

451

452

453

Koslow J.A., Boehlert G.W., Gordon J.D.M., Haedrich R.L., Lorance P., Parin N. (2000) Continental slope and deep-sea fisheries: implications for a fragile ecosystem. ICES Journal of Marine Science 57:548-557

Larcom E.A., Mckean D.L., Brooks J.M. and Fisher C.R. (2014) Growth rates densities and distribution of Lophelia pertusa on artificial structures in the Gulf of Mexico. Deep-sea Research 15, 101-109.

Lartaud F., Pareige S., De Rafelis M., Feuillassier L., Bideau M., Peru E., Romans P., Alcala F. and Le Bris N. (2013) A new approach for assessing cold-water coral growth in situ using fluoresdent calcein staining. Aquatic Living Resources 26, 187-196.

Maier C., Schubert A., Sanchez M.M.B., Weinbauer M.G., Watremez P. and Gattuso J.P. (2013) End of century $\mathrm{pCO}_{2}$ levels do not impact calcification in Mediterranean cold-water corals. PLoS ONE 8, 1-9.

McCulloch M., Trotter J., Montagna P. Falter J., Dunbar R., Freiwlad A., Försterra G., López Correa M., Maier C., Rüggeberg A and Taviani M. (2012) Resilience of coldwater scleractinian corals to ocean acidification: Boron isotopic systematics of $\mathrm{pH}$ and 
saturation state up-regulation. Geochimica et Cosmochimica 87, 21-34.

467

468

469

470

471

472

473

474

475

476

477

478

479

480

481

482

483

484

485

486

487

488

McFadden C.S. (1986) Colony fission increases particle capture rates of a soft coral: advantages of being a small colony. Journal of Experimental Marine Biology and Ecology 103, 1-20.

Mienis F., de Stigter H.C., White M., Duineveld G., de Haas H., van Weering T.C.E. (2007) Hydrodynamic controls on cold-water coral growth and carbonate-mound development at the SW and SE Rockall Trough Margin, NE Atlantic Ocean. Deep-Sea Research I 54, 16411654.

Miller M.W. (1995) Growth of a temperate coral: effects of temperature, light, depth and heterotrophy. Marine Ecology Progress Series 122, 217-225.

Moreno-Navas J., Miller P.L., Henry L.A., Hennige S.J. and Roberts J.M. (2014)

Ecohydrodynamics of cold-water coral reefs: a case study of the Mingulay Reef Complex (western Scotland). PloS One 9, 1-12.

Movilla J., Orejas C., Calvo E., Gori A., López-Sanz À., Grinyó J., Domínguez-Carrió C. and Pelejero C. (2014) Differential response of two Mediterranean cold-water coral species to ocean acidification. Coral Reefs 33, 675-686.

Naumann M.S., Orejas C. and Ferrier-Pagès C. (2014) Species-specific physiological response by the cold-water corals Lophelia pertusa and Madrepora oculata to variations within their natural temperature range. Deep-Sea Research II 99, 36-41.

Olariaga A., Gori A., Orejas C., Gili J.M. and Roberts J.M. (2009) Development of an autonomous aquarium system for maintaining deep corals. Oceanography 22, 44-45.

Orejas C., Gori A. and Gili J. M. (2008) Growth rates of live Lophelia pertusa and Madrepora oculata from Mediterranean Sea maintained in aquaria. Coral Reefs 27, 255-255.

Orejas C., Gori A., Lo Iacono C., Puig P., Gili J.M. and Dale M.R.T. (2009) Cold-water 
corals in the Cap de Creus canyon, northwestern Mediterranean: spatial distribution, density and anthropogenic impact. Marine Ecology Progress Series 397, 37-51.

491 Orejas C., Ferrier-Pages C., Reynaud S., Tsounis G., Allemand D. and Gili J.M. (2011a)

492 Experimental comparison of skeletal growth rates in the cold-water coral Madrepora oculata Linnaeus, 1758 and three tropical scleractinian corals. Journal of Experimental Marine Biology and Ecology 405, 1-5.

Orejas C., Ferrier-Pages C., Reynaud S., Tsounis G., Allemand D. and Gili J.M. (2011b) Long-term growth rates of four Mediterranean cold-water coral species maintained in aquaria. Marine Ecology Progress Series 429, 57-65.

Orejas C., Gori A., Rad-Menéndez C., Last K.S., Davies A.J., Beveridge C.M., Sadd D., Kiriakoulakis K., Witte U. and Roberts J.M. (2016) Capture efficiency and feeding behaviour of the cold-water coral Lophelia pertusa: flow speed and food size make a difference. Journal of Experimental Marine Biology and Ecology.

Purser A., Larsson A.I., Thomsen L. and van Oevelen D. (2010) The influence of flow velocity and food concentation on Lophelia pertusa zooplankton capture rates. Journal of Experimental Marine Biology and Ecology 395, 55-62.

Purser A., Orejas C., Gori A., Tong R., Unnithan V. and Thomsen L. (2013) Local variation in the distribution of benthic megafauna species associated with cold-water coral reefs on the Norwegian margin. Continental Shelf Research 54, 37-51.

Reed J.K. (2002) Deep-water Oculina coral reefs of Florida: biology, impacts and management. Hydrobiologia 471, 43-55.

510 Ribes M., Coma R. and Gili J.M. (1998) Heterotrophic feeding by gorgonian corals with 511 symbiotic zooxanthella. Limnology and Oceanography 43, 1170-1179. 
512 Roberts J.M. and Anderson R.M. (2002) A new laboratory method for monitoring deep-sea

513 coral polyp behaviour. Hydrobiologia 471, 143-148.

514 Roberts J.M., Brown C.J., Long D. and Bates C.R. (2005) Acoustic mapping using a

515 multibeam echosounder reveals cold-water coral reefs and surrounding habitats. Coral Reefs

$516 \quad 24,654-669$.

517 Roberts J.M., Wheeler A.J. and Freiwald A. (2006) Reefs of the deep: the biology and 518 geology of cold-water coral ecosystems. Science 312, 543-547.

519 Roberts J.M., Davies A.J., Henry L.A., Dodds L.A., Duineveld G.C.A., Lavaleye M.S.S.,

520 Maier C., van Soest R.W.M., Bergman M.J.N., Hühnerbach V., Huvenne V.A.I.,

521 Sinclair D.J., Watmough T., Long D., Green S.L. and van Haren H. (2009) Mingulay

522 reef complex: an interdisciplinary study of cold-water coral habitat, hydrography and

523 biodiversity. Marine Ecology Progress Series 397, 139-151.

524 Roberts J.M. and shipboard party (2013) Changing Oceans Expedition 2012. RRS James

525 Cook 073 Cruise Report. Heriot-Watt University, 224 pp.

526 Rogers A. (2004) The biology, ecology and vulnerability of deep-water coral reefs. IUCN, 13pp.

527 Sebens K.P., Grace S.P., Helmuth B.S.T., Maney E.J. and Miles J.S. (1998) Water flow and

528 prey capture by three scleractinian corals Madracis mirabilis, Monstastrea cavernosa and

529 Porites porites, in a field enclosure. Marine Biology 131, 347-360.

530 Smith L.W., Barshis D. and Birkeland C. (2007) Phenotypic plasticity for skeletal growth,

531 density and calcyfication of Porites lobata in response to habitat type. Corel Reefs 26, 559-

$532 \quad 567$.

533 Thresher R.E. (2009) Environmental and compositional correlates of growth rate in deep-water

534 bamboo corals (Gorgonacea; Isididae). Marine Ecology Progress Series 397, 187-196. 
535 Via S. and Lande R. (1985) Genotype-environment interaction and the evolution of phenotypic 536 plasticity. Evolution 39, 505-522.

537 Wagner H., Purser A., Thomsen L., Jesus C.C. and Lundälv T. (2011) Particulate organic

538 matter fluxes and hydrodynamics at the Tisler cold-water coral reef. Journal of Marine

539 Systems 85:19-29.

540 Willis B.L. and Ayre D.J. (1985) Asexual reproduction and genetic determination of growth

541 form in the coral Pavona cactus: Biochemical genetic and immunogenic evidence.

$542 \quad$ Oecologia $65,516-525$.

543 Wilson J.B. (1979) Patch Development of the Deep-Water Coral Lophelia pertusa on Rockall

544 Bank. Journal of the Marine Biological Association of the United Kingdom 59, 165-177.

545 Wynn R.B., Huvenne V.A.I., Le Bas T.P., Murton B.J., Connelly D.P., Bett B.J., Ruhl H.A., 546 Morris K.J., Peakall J., Parsons D.R., Sumner E.J., Darby S.E., Dorrell R.M. and Hunt

547 J.E. (2014). Autonomous underwater vehicles (AUVs): their past, presence and future

548 contributions to the advancement of marine geoscience. Marine Geology 352, 451-468. 


\section{Figures and Tables}

550

551 Fig. 1. (A) Mingulay Reef Complex (MRC) and PISCES area location offshore Scotland (B)

552 Colonies 1 to $14(\mathrm{C} 1$ to $\mathrm{C} 14)$ locations within MRC. Note that colony 5 (C5) is the only colony

553 located on Banana Reef (C) Colonies 15 to 18 (C15 to C18) locations within PISCES area.
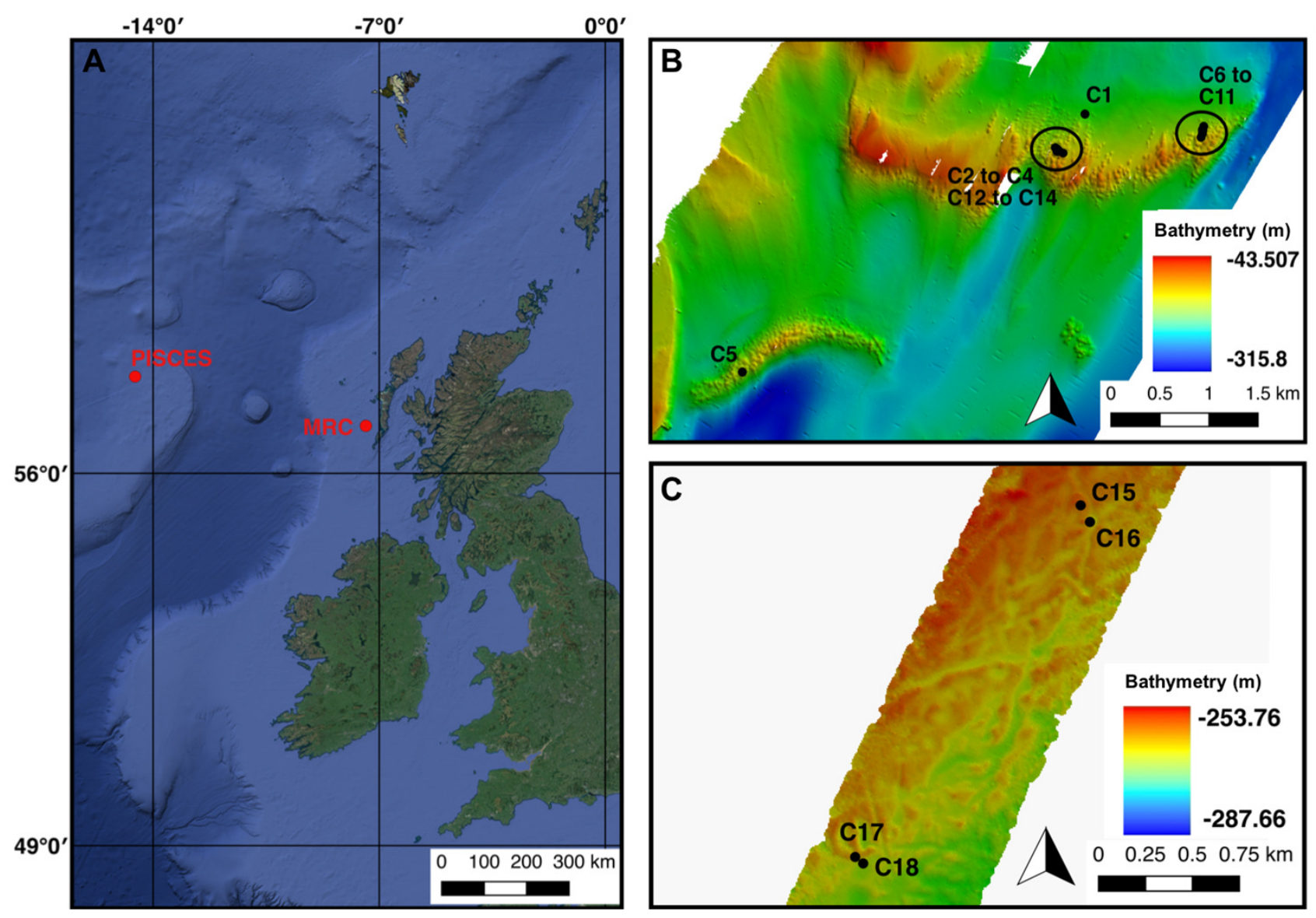
555 Fig. 2. Method applied to measure living and dead layers of a colony at Mingulay Reef Complex.

556 (A) Original capture from the video record. (B) Colours black, brown, red and orange display

557 different polyp layers from the front part of the colony to the back, green colour display the

558 groups of polyps which are in the same layer/plane which have been chosen to measure the dead

559 and the living layer. (C) Schematic image of the different plains of the colony represented by the

560 different colours, the bi-colour bars represent the measure of the layers starting at the basis of the

561 colony the measure of the dead layer (red), and represented in orange the living layer of the

562 colony. Any measure made in the green area correspond to the same plane. (D) original image

563 with the measure bars.
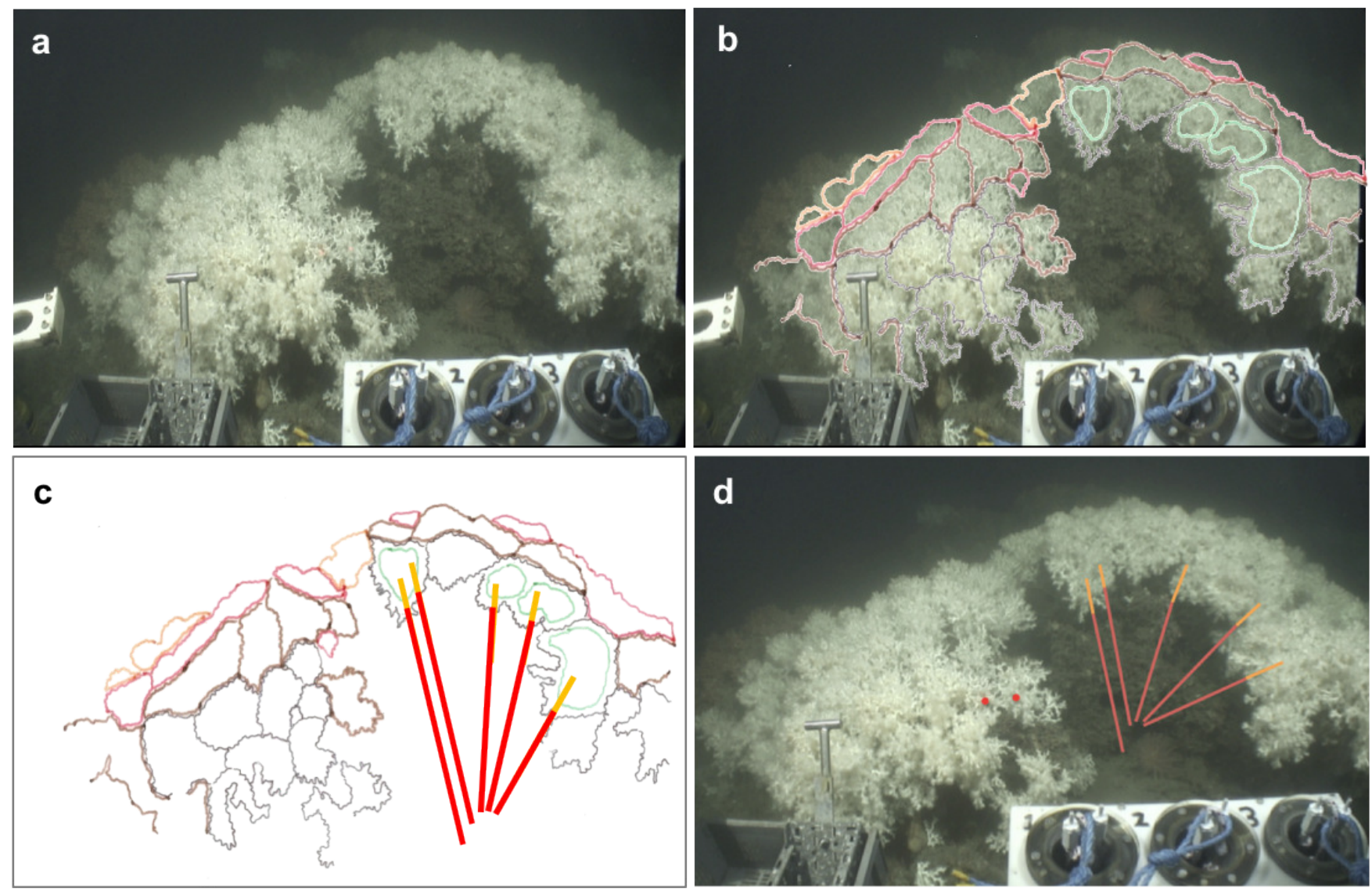
565 Fig. 3. Method applied to measure living and dead layers of a colony at Pisces. (A) Original

566 capture from the video record. (B) Colours black, brown, red and orange display different polyp

567 layers from the front part of the colony to the back, green colour display the groups of polyps

568 which are in the same layer/plane which have been chosen to measure the dead and the living

569 layer. (C) Schematic image of the different plains of the colony represented by the different

570 colours, the bi-colour bars represent the measure of the layers starting at the basis of the colony

571 the measure of the dead layer (red), and represented in orange the living layer of the colony. Any

572 measure made in the green area correspond to the same plane. (D) original image with the

573 measure bars.
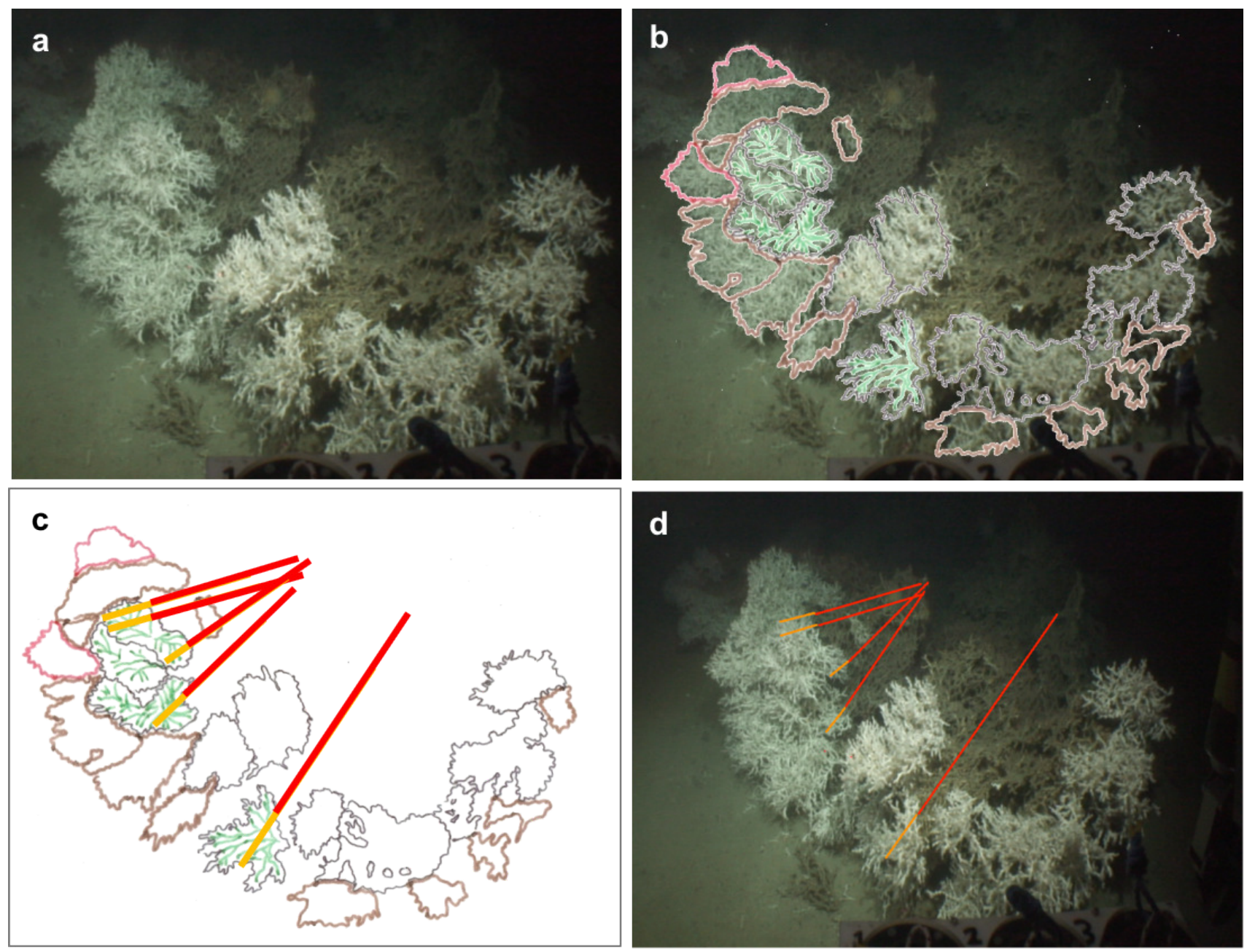
575 Fig. 4. Lophelia pertusa A) number of colonies belonging to the different size ranges detected in

576 the Mingulay Reef Complex (MRC) and the PISCES area and B) Living (grey) and dead

577 (antracit) layer sizes for the 20 L. pertusa colonies analysed (14 from MRC, including colony 5

578 which has been recorded in Banana Reef; 5 from PISCES). Error bars display the SD.

A

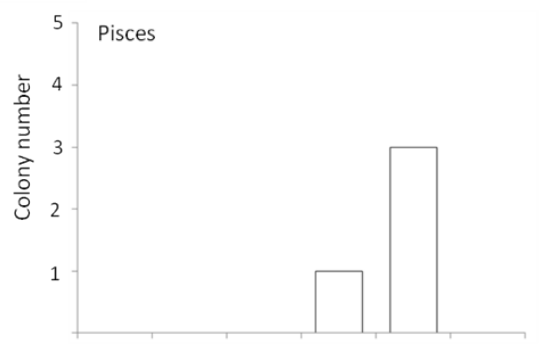

Mingulay Reef

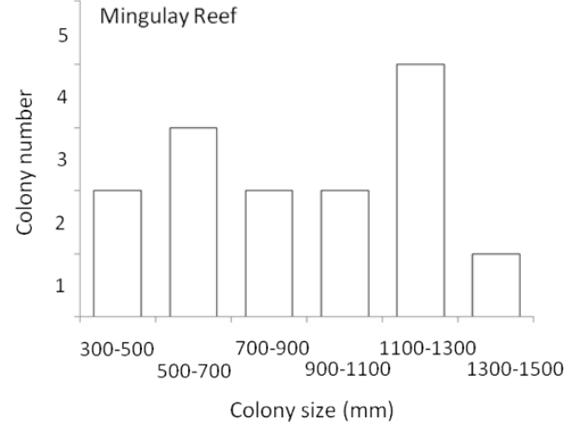

B

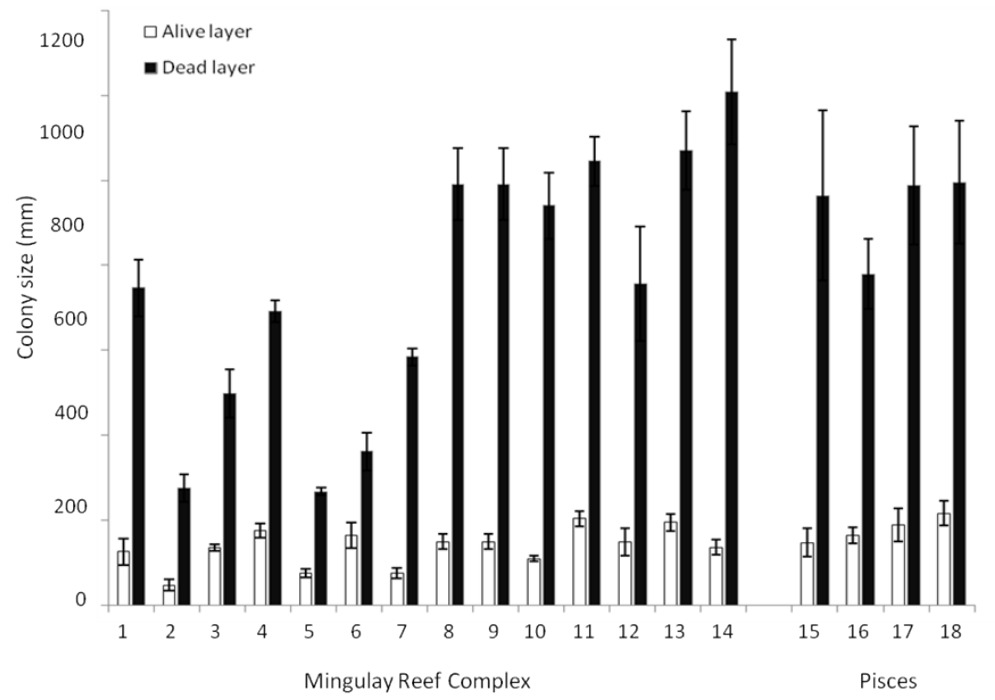

579 
580 Figure 5: Scatterplot of living layer thickness (A) and L: W ratio (B) as a function of total colony

581 sizes. Measurements from MRC colonies are displayed in black; measurements from PISCES

582 colonies are displayed in grey. Regression lines for each plot are traced in green.
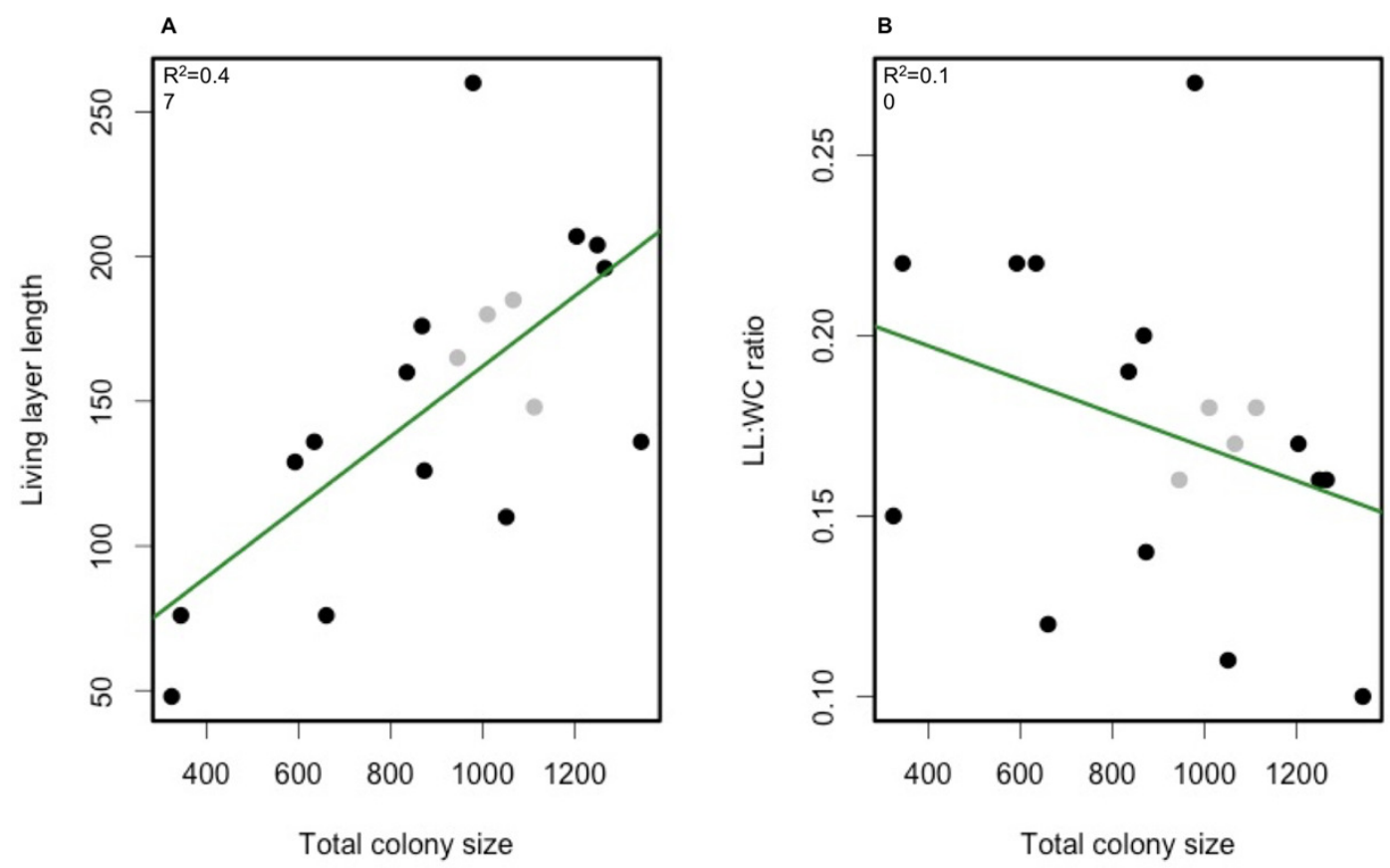
584 Figure 6: T-S plot showing the potential temperature $v s$ salinity (sal), with isopycnals (grey lines)

585 for all the ROV transects. Colours represent the different transects (and sites): blue colours show

586 the transects within the Mingulay Reef Complex (MRC) while red colours show the transects

587 within the PISCES areas (PA).

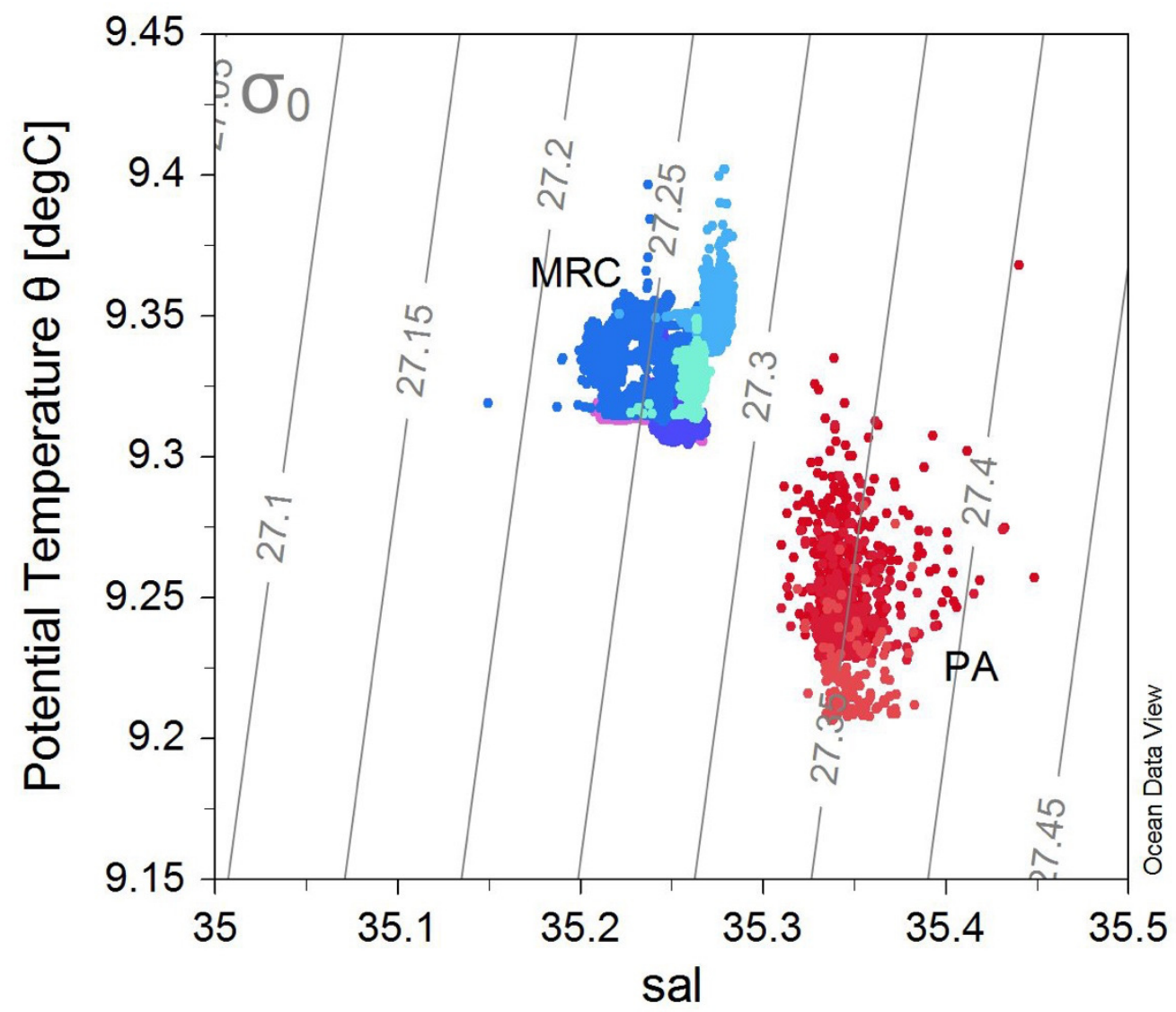


588 Table 1: Transect number, location, coordinates (latitude longitude) at the start and the end of 589 each transect, depth $(\mathrm{m})$ at the start and the end of the transect, length $(\mathrm{m})$ and number of 590 selected colonies analysed in this study. MR: Mingulay Reef, BR: Banana Reef.

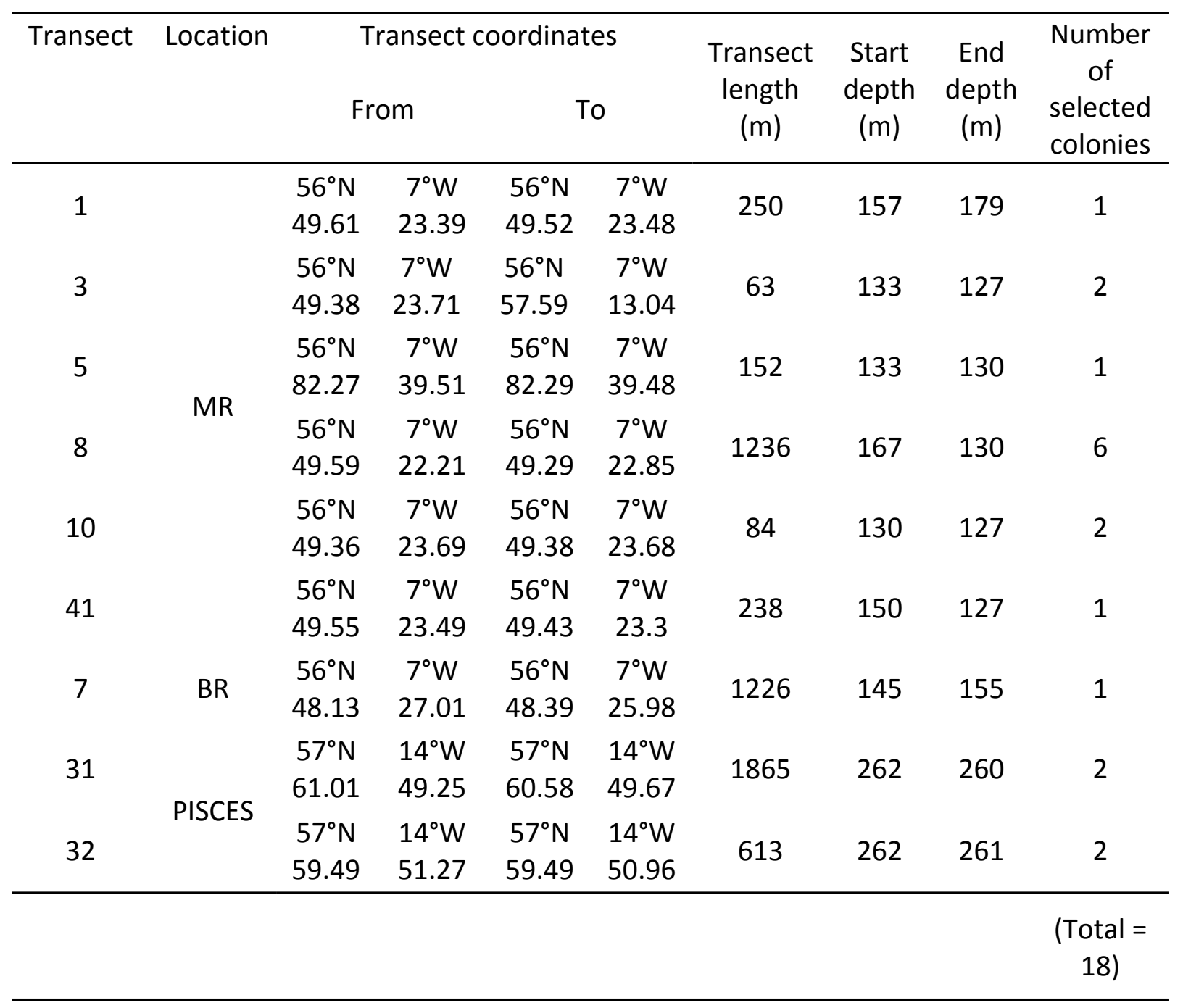


592 Table 2: Lophelia pertusa colony layer and whole size measurements ( $\mathrm{mm} \pm \mathrm{SD}$ ) and Living layer:

593 Whole size ratio estimation (LL: WC) and age estimation based on Gass and Roberts 2006. *

594 Colony 5 is the only colony present at Banana Reef. Transect number is displayed between

595 brackets in the second column.

\begin{tabular}{|c|c|c|c|c|c|c|}
\hline Area & $\begin{array}{l}\text { Colony } \\
\text { number }\end{array}$ & $\begin{array}{l}\text { Dead layer } \\
(\mathrm{mm})\end{array}$ & $\begin{array}{l}\text { Living layer } \\
(\mathrm{mm})\end{array}$ & $\begin{array}{l}\text { Total colony } \\
\text { size }(\mathrm{mm})\end{array}$ & $\begin{array}{c}\text { Living layer: } \\
\text { whole size } \\
\text { ratio } \\
\end{array}$ & $\begin{array}{c}\text { Age estimation } \\
\text { (years) }\end{array}$ \\
\hline \multirow{14}{*}{$\begin{array}{l}\text { Mingulay } \\
\text { Reef } \\
\text { Complex }\end{array}$} & $1(1)$ & $747 \pm 66$ & $126 \pm 30$ & $873 \pm 90$ & $0.14 \pm 0.02$ & $34.9 \pm 7.9$ \\
\hline & $2(3)$ & $276 \pm 32$ & $48 \pm 13$ & $324 \pm 43$ & $0.15 \pm 0.02$ & $12.9 \pm 3.1$ \\
\hline & $3(3)$ & $498 \pm 57$ & $136 \pm 7$ & $634 \pm 64$ & $0.22 \pm 0.01$ & $25.3 \pm 5.7$ \\
\hline & $4(5)$ & $692 \pm 25$ & $176 \pm 16$ & $868 \pm 32$ & $0.20 \pm 0.02$ & $34.7 \pm 7.1$ \\
\hline & $5^{*}(7)$ & $719 \pm 75$ & $260 \pm 10$ & $979 \pm 75$ & $0.27 \pm 0.02$ & $39.1 \pm 8.4$ \\
\hline & $6(8)$ & $584 \pm 21$ & $76 \pm 13$ & $660 \pm 23$ & $0.12 \pm 0.02$ & $26.4 \pm 5.4$ \\
\hline & $7(8)$ & $463 \pm 52$ & $129 \pm 19$ & $592 \pm 37$ & $0.22 \pm 0.05$ & $23.7 \pm 5.0$ \\
\hline & $8(8)$ & $997 \pm 73$ & $207 \pm 26$ & $1204 \pm 87$ & $0.17 \pm 0.02$ & $48.1 \pm 10.3$ \\
\hline & $9(8)$ & $940 \pm 78$ & $110 \pm 7$ & $1051 \pm 79$ & $0.11 \pm 0.01$ & $42.0 \pm 9.0$ \\
\hline & $10(8)$ & $1045 \pm 58$ & $204 \pm 17$ & $1249 \pm 66$ & $0.16 \pm 0.01$ & $49.9 \pm 10.4$ \\
\hline & $11(8)$ & $675 \pm 89$ & $160 \pm 28$ & $835 \pm 104$ & $0.19 \pm 0.03$ & $33.3 \pm 7.8$ \\
\hline & $12(10)$ & $1070 \pm 92$ & $196 \pm 20$ & $1265 \pm 95$ & $0.16 \pm 0.02$ & $50.5 \pm 10.9$ \\
\hline & $13(10)$ & $1208 \pm 124$ & $136 \pm 18$ & $1344 \pm 115$ & $0.10 \pm 0.02$ & $53.7 \pm 11.7$ \\
\hline & $14(41)$ & $268 \pm 9$ & $76 \pm 10$ & $344 \pm 19$ & $0.22 \pm 0.02$ & $13.7 \pm 2.9$ \\
\hline \multirow{4}{*}{ PISCES } & $15(31)$ & $964 \pm 200$ & $148 \pm 33$ & $1112 \pm 226$ & $0.13 \pm 0.02$ & $44.4 \pm 12.5$ \\
\hline & $16(31)$ & $780 \pm 82$ & $165 \pm 19$ & $945 \pm 70$ & $0.18 \pm 0.03$ & $37.7 \pm 8.1$ \\
\hline & $17(32)$ & $946 \pm 181$ & $181 \pm 38$ & $1057 \pm 155$ & $0.17 \pm 0.03$ & $45.0 \pm 10.9$ \\
\hline & $18(32)$ & $828 \pm 53$ & $180 \pm 32$ & $1010 \pm 71$ & $0.18 \pm 0.03$ & $40.3 \pm 8.6$ \\
\hline
\end{tabular}


597 Table 3: Two sided two samples Wilcoxon test comparing mean dead layer thickness, mean living 598 layer thickness, mean whole colony size and mean LL:WC ratio between MRC and Pisces sites.

\begin{tabular}{lrr}
\cline { 2 - 3 } & \multicolumn{2}{c}{ Two-sample Wilcoxon test } \\
\cline { 2 - 3 } & Wilcoxon W & p-Value \\
\hline Dead layer thickness & 14 & $\mathbf{0 . 1 5 1 5}$ \\
Living layer thickness & 15 & $\mathbf{0 . 1 8 3 7}$ \\
Whole colony size & 19 & $\mathbf{0 . 3 8 1 7}$ \\
LL:WC ratio & 29.5 & $\mathbf{0 . 9 1 5}$ \\
\hline
\end{tabular}

599 
600 Table 4: Depth $(\mathrm{m})$, average current speed (m/s), current speed standard deviation $(\mathrm{m} / \mathrm{s})$,

601 maximum current speed $(\mathrm{m} / \mathrm{s})$, aspect $\left(^{\circ}\right)$, slope $\left(^{\circ}\right)$ and rugosity (um) values extracted from

602 Moreno-Navas et al.'s (2014) hydrodynamic model at each MRC colony location.

\begin{tabular}{cccccccc}
\hline $\begin{array}{c}\text { Colony } \\
\text { Number }\end{array}$ & $\begin{array}{c}\text { Depth } \\
(\mathrm{m})\end{array}$ & $\begin{array}{c}\text { Average } \\
\text { current } \\
\text { velocity }(\mathrm{m} / \mathrm{s})\end{array}$ & $\begin{array}{c}\text { Standard } \\
\text { deviation current } \\
\text { velocity }(\mathrm{m} / \mathrm{s})\end{array}$ & $\begin{array}{c}\text { Maximum } \\
\text { average current } \\
\text { velocity }(\mathrm{m} / \mathrm{s})\end{array}$ & $\begin{array}{c}\text { Aspect } \\
\left({ }^{\circ}\right)\end{array}$ & $\begin{array}{c}\text { Slope } \\
\left({ }^{\circ}\right)\end{array}$ & $\begin{array}{c}\text { Rugosity } \\
(\mu \mathrm{m})\end{array}$ \\
\hline $1(1)$ & 173.28 & 0.277 & 0.126 & 0.527 & 19.854 & 6.602 & 1.010 \\
$2(3)$ & 132.78 & 0.340 & 0.155 & 0.636 & 30.360 & 7.250 & 1.020 \\
$3(3)$ & 126.89 & 0.336 & 0.157 & 0.637 & 334.868 & 9.826 & 1.185 \\
$4(5)$ & 131.02 & 0.336 & 0.157 & 0.637 & 247.241 & 12.998 & 1.049 \\
$5^{*}(7)$ & 143.86 & 0.296 & 0.074 & 0.450 & 81.671 & 0.551 & 1.001 \\
$6(8)$ & 146.16 & 0.291 & 0.150 & 0.548 & 325.656 & 13.823 & 1.061 \\
$7(8)$ & 141.16 & 0.291 & 0.150 & 0.548 & 319.689 & 21.306 & 1.092 \\
$8(8)$ & 139.56 & 0.291 & 0.150 & 0.548 & 312.903 & 17.594 & 1.103 \\
$9(8)$ & 139.56 & 0.291 & 0.150 & 0.548 & 312.903 & 17.594 & 1.065 \\
$10(8)$ & 133.32 & 0.291 & 0.150 & 0.548 & 355.539 & 18.234 & 1.072 \\
$11(8)$ & 134.09 & 0.291 & 0.150 & 0.548 & 316.595 & 8.603 & 1.031 \\
$12(10)$ & 131.02 & 0.336 & 0.157 & 0.637 & 247.241 & 12.998 & 1.049 \\
$13(10)$ & 127.81 & 0.336 & 0.157 & 0.637 & 100.052 & 13.021 & 1.039 \\
$14(41)$ & 129.65 & 0.336 & 0.157 & 0.637 & 317.906 & 9.844 & 1.061 \\
\hline 603 & & & & & & &
\end{tabular}

